\title{
Pyrolysis characteristics of sediment from the Dianchi Lake
}

\author{
Zhenfen $\mathrm{Wu}^{1,2, \mathrm{a}}$, Huilong Luo ${ }^{1, \mathrm{~b}}$ \\ ${ }^{1}$ Faculty of Architecture Engineering, Kunminng University of Science and Technology, Kunming \\ 650500, China \\ ${ }^{2}$ Faculty of Modern Agricultural Engineering, Kunminng University of Science and Technology, \\ Kunming 650500, China
}

a823832184@qq.com, b km_lhl@163.com

Keywords: Lake sediment, Pyrolysis, TG analysis, Heating rate

\begin{abstract}
Pyrolysis properties of Dianchi lake sediment in China at $10^{\circ} \mathrm{C} / \mathrm{min}$ and $20^{\circ} \mathrm{C} / \mathrm{min}$ were investigated by TG. Comparison to the TG and DTG curves at different heating rates, the pyrolysis reaction at $10^{\circ} \mathrm{C} / \mathrm{min}$ was in advance and more completely than at $20^{\circ} \mathrm{C} / \mathrm{min}$, thus the process of sediment pyrolysis could be considered as four stages, which were the release stage of moisture and crystal water, the decomposition of light organic compounds, the decomposition of macromolecule organic matters and secondary cracking of tar and coke, and the decomposition of mineral salts. The results could provide theoretical basis for harmless treatment and resource utilization of lake sediment.
\end{abstract}

\section{Introduction}

Lake sediment is transformation carrier of a large number of organic pollutants in the environment, which can be regarded as the second pollution source of water[1-2]. At present, the most common sediment treatment methods are containing preparation of fertilizer, landfill, pyrolysis and preparation of building material[3]. However, considering heavy metal harm and the farm limitations, the landfill and building material as well as preparation of fertilizer are becoming more and more difficult to operate[4-5]. Thus, pyrolysis was identified to be a promising treatment technology of sediment[6]. Several reports studied some characteristics of lake sediment. Wang et al.[7] studied co-gasification of sediment and lignite for hydrogen production in supercritical water. $\mathrm{Gu}$ et al.[8] studied the variation of heavy metal speciation during pyrolysis of sediment. However, few studies focused on pyrolysis process and characteristc for lake sediment. In order to obtain a better understanding of the chemical and physical characteristics of lake sediment pyrolysis as well as reasonable mechanism, it is necessary to do many contributions on the TG study of lake sediment pyrolysis.Thermogravimetric(TG) analysis is one of the most common thermal analysis techniques[9-10]. The purpose of this work was to investigate the pyrolysis characteristics of Dianchi Lake sediment through TG analysis at different heating rates.

\section{Materials and methodology}

\subsection{Materials}

The raw lake sediment was collected from the Caihai region of the Dianchi Lake in Kunming, China, and the moisture content that measured by air oven was $68.25 \%$. The sediment was subjected to drying (378K for 24h), crushing and screening(through a 200 mesh sieve). The ultimate analysis and proximate analysis of the raw material are shown in Table 1, and Table 2 shows ash composition analysis of the raw material.

Table 1 Ultimate analysis and proximate analysis of the raw sediment

\begin{tabular}{|c|c|c|c|c|c|c|c|c|c|}
\hline \multirow{2}{*}{ Material } & \multicolumn{5}{|c|}{ Ultimate analysis (wt\%) } & \multicolumn{4}{|c|}{ proximate analysis (wt \%) } \\
\hline & $\mathrm{C}$ & $\mathrm{H}$ & $\mathrm{O}$ & $\mathrm{N}$ & $\mathrm{S}$ & $\mathrm{M}$ & $\mathrm{V}$ & FC & $\mathrm{A}$ \\
\hline Sediment & 22.24 & 2.98 & 28.15 & 1.56 & 1.48 & 8.44 & 40.46 & 7.67 & 43.43 \\
\hline
\end{tabular}


Table 2 Ash composition analysis of the raw sediment (wt\%)

\begin{tabular}{lcccccccccccc}
\hline & $\mathrm{SiO}_{2}$ & $\mathrm{Al}_{2} \mathrm{O}_{3}$ & $\mathrm{Fe}_{2} \mathrm{O}_{3}$ & $\mathrm{CaO}$ & $\mathrm{K}_{2} \mathrm{O}$ & $\mathrm{MgO}$ & $\mathrm{TiO}_{2}$ & $\mathrm{P}_{2} \mathrm{O}_{5}$ & $\begin{array}{l}\mathrm{Na}_{2} \\
\mathrm{O}\end{array}$ & $\mathrm{CuO}$ & $\mathrm{ZnO}$ & $\mathrm{NiO}$ \\
\hline Ash & 34.11 & 21.02 & 17.27 & 9.34 & 3.38 & 2.52 & 1.91 & 1.14 & 0.11 & 0.06 & 0.04 & 0.02 \\
\hline
\end{tabular}

\subsection{TG analysis}

The thermal pyrolysis experiments of the raw sediment were carried out online by a TGA type(NETZSCH, STA 449F3,Germany). Firstly pass N2 for $5 \mathrm{~min}$ at $30 \mathrm{~mL} / \mathrm{min}$, then about 3.7-4.2mg samples were inserted into the TGA apparatus. The samples were heated from $40^{\circ} \mathrm{C}$ to $1000^{\circ} \mathrm{C}$ at two different heating rates $\left(10^{\circ} \mathrm{C} / \mathrm{min}\right.$ and $\left.20^{\circ} \mathrm{C} / \mathrm{min}\right)$. In order to reduce the test error to less than $5 \%$, all the tests were repeated three times.

\section{TG and DTG analysis from pyrolysis of sediment}

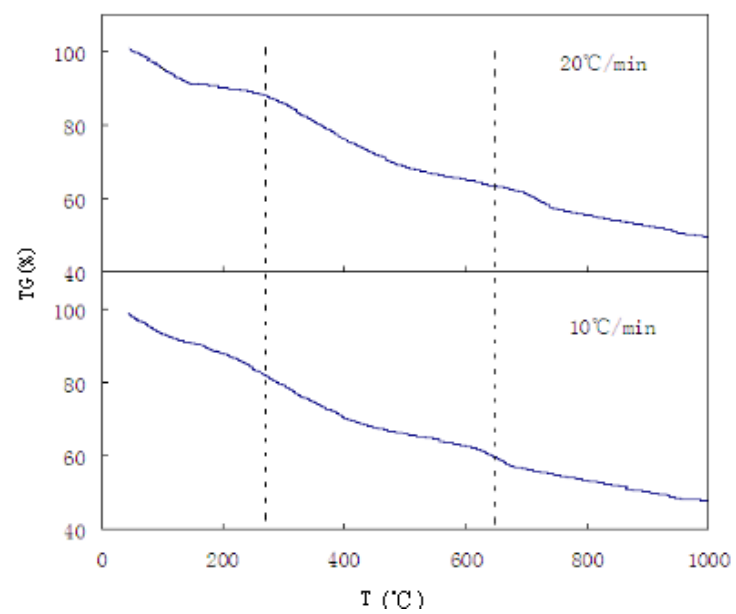

Fig.1 The TG curves for pyrolysis of sediment at different heating rates

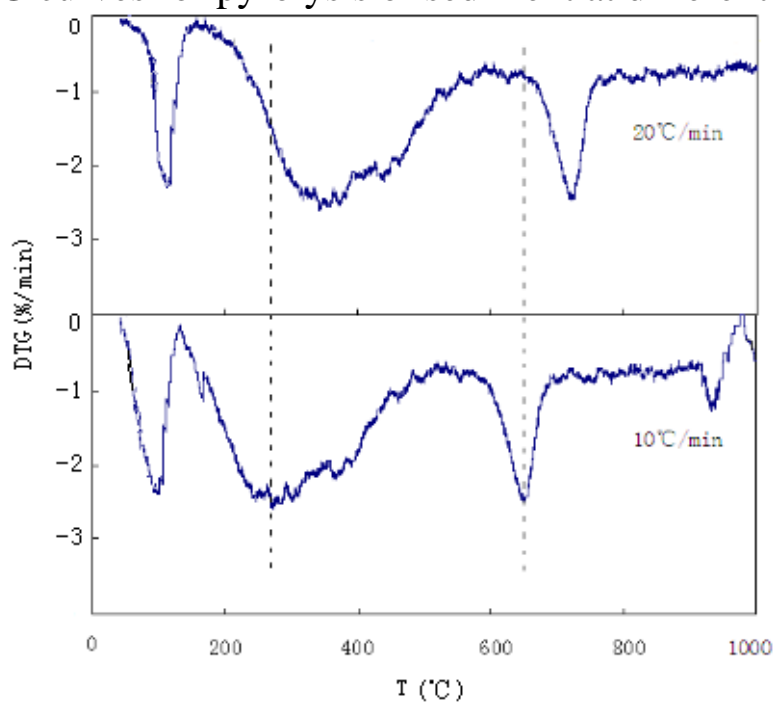

Fig.2 The DTG curves for pyrolysis of sediment at different heating rates

The TG and DTG curves of sediment pyrolysis at $10^{\circ} \mathrm{C} / \mathrm{min}$ and $20^{\circ} \mathrm{C} / \mathrm{min}$ were shown in Fig. 1 and Fig. 2 respectively. As shown in Fig.1, the remaining mass fraction curve was shifted down the temperature scale with the heating rate decreasing. From the Fig.2, it is seen that there were four weight loss peaks at $10^{\circ} \mathrm{C} / \mathrm{min}$, but there were three weight loss peaks at $20^{\circ} \mathrm{C} / \mathrm{min}$. The devolatilization process of sediment occurred in a range of temperature between $200^{\circ} \mathrm{Cand} 800^{\circ} \mathrm{C}$. The characteristic parameters for sediment sample pyrolysis at two heating rates were presented in Table 3, it is known that the temperatures according to the first, the second, the third and the forth weight loss peaks at $20^{\circ} \mathrm{C} / \mathrm{min}$ were higher than that at $10^{\circ} \mathrm{C} / \mathrm{min}$, respectively. It is indicated that the occurrence of weight loss peaks tended to low temperature region with a decrease of heating rate. Meanwhile, the maximum mass loss rates according to the first, the second, the third and the 
forth peaks were slightly lower at $20^{\circ} \mathrm{C} / \mathrm{min}$ than that at $10^{\circ} \mathrm{C} / \mathrm{min}$, respectively. It is indicated that the reaction was more intense with a decrease of heating rate. Meanwhile, the higher Mf value and the lack of the forth peak at $20^{\circ} \mathrm{C} / \mathrm{min}$ indicated that the pyrolysis reaction of sediment might be incomplete at $20^{\circ} \mathrm{C} / \mathrm{min}$. Thus, the pyrolysis process at $10^{\circ} \mathrm{C} / \mathrm{min}$ could demonstrated the sediment pyrolysis characteristics better than at $20^{\circ} \mathrm{C} / \mathrm{min}$.

Table 3 Characteristic parameters for sediment pyrolysis at different heating rates

\begin{tabular}{cccccccccc}
\hline $\begin{array}{c}\text { Heating rate } \\
\left({ }^{\circ} \mathrm{C} / \mathrm{min}\right)\end{array}$ & $\begin{array}{c}\mathrm{T}_{1}{ }^{\mathrm{a}} \\
\left({ }^{\circ} \mathrm{C}\right)\end{array}$ & $\begin{array}{c}\mathrm{T}_{2}{ }^{\mathrm{a}} \\
\left({ }^{\circ} \mathrm{C}\right)\end{array}$ & $\begin{array}{c}\mathrm{T}_{3}{ }^{\mathrm{a}} \\
\left({ }^{\circ} \mathrm{C}\right)\end{array}$ & $\begin{array}{c}\mathrm{T}_{4}{ }^{\mathrm{a}} \\
\left({ }^{\circ} \mathrm{C}\right)\end{array}$ & $\begin{array}{c}\mathrm{DTG}_{\max 1}{ }^{\mathrm{b}} \\
(\% / \min )\end{array}$ & $\begin{array}{c}\mathrm{DTG}_{\max 2}{ }^{\mathrm{b}} \\
(\% / \min )\end{array}$ & $\begin{array}{c}\mathrm{DTG}_{\max 3}{ }^{\mathrm{b}} \\
(\% / \min )\end{array}$ & $\begin{array}{c}\mathrm{DTG}_{\max 4}{ }^{\mathrm{b}} \\
(\% / \min )\end{array}$ & $\begin{array}{c}\mathrm{M}_{\mathrm{f}}{ }^{\mathrm{c}} \\
(\%)\end{array}$ \\
\hline 20 & 112.25 & 359.85 & 728.73 & $/$ & -2.30 & -2.67 & -2.54 & $/$ & 52.17 \\
10 & 100.78 & 290.14 & 650.38 & 920.67 & -2.41 & -2.68 & -2.63 & -1.25 & 50.36 \\
\hline
\end{tabular}

${ }^{\mathrm{a}} \mathrm{T}_{1}, \mathrm{~T}_{2}, \mathrm{~T}_{3}, \mathrm{~T}_{4}$, the temperature according to the first, the second, the third and the forth weight loss peak respectively.

${ }^{\mathrm{b}} \mathrm{DTG}_{\max 1}, \mathrm{DTG}_{\max 2}, \mathrm{DTG}_{\max 3}$, DTG $\mathrm{max}_{\max }$, the maximum mass loss rate according to the first, the second, the third and the forth peak respectively.

${ }^{\mathrm{c}} \mathrm{M}_{\mathrm{f}}$, the residual mass fraction.

During the whole sediment pyrolysis process at $10^{\circ} \mathrm{C} / \mathrm{min}$, four stages were considered: (a) in the first stage ranged from $40^{\circ} \mathrm{C}$ to $160^{\circ} \mathrm{C}$, the total weight loss was accounting for $12.15 \%$ of total weight of sample, which was attributed to the loss of $8.44 \%$ moisture (shown in Table 1 ) and crystal water, as well as the decomposition of a given amount of small-molecule reactive components. (b) the second stage while the temperature was from $160^{\circ} \mathrm{C}$ to $520^{\circ} \mathrm{C}$, the total weight loss was accounting for $23.36 \%$, the volatile matter of an enormous amount of light organic compounds such as macromolecule organic matters such as saturated aliphatic chains, cellulose and semicellulose polysaccharides and proteins, as well as alcohols and saccharides, were mainly decomposed in this stage. The products of the stage were mainly combustible gas,carbon dioxide, coke and tar. (c)the third stage was from $520^{\circ} \mathrm{C}$ to $780^{\circ} \mathrm{C}$, the weight loss was accounting for about $10.41 \%$, which was attributed to the decomposition of a small part of secondary cracking of tar and macromolecule organic matters and coke generated in the second stage. (d) the fourth stage was above $780^{\circ} \mathrm{C}$, the total weight loss was accounting for $6.25 \%$. As shown in Table 2, this stage was mainly due to the partly decomposition of mineral salts such as combinations of other oxides (mostly metal oxide) and SiO2. As for at the heating rate of $20^{\circ} \mathrm{C} / \mathrm{min}$, three stages were considered. The first stage was ranged from $40^{\circ} \mathrm{C}$ to $180^{\circ} \mathrm{C}$, the total weight loss was accounting for $10.55 \%$ of total weight of sample, which was attributed to the loss of moisture and crystal water. The second stage was ranged from $180^{\circ} \mathrm{C}$ to $600^{\circ} \mathrm{C}$, the total weight loss was accounting for $27.54 \%$, which was due to the decomposition of a large number of macromolecule organic matters and light organic compounds. The third stage was above $600^{\circ} \mathrm{C}$, the total weight loss was accounting for $12.27 \%$, which was due to decomposition of inorganic matters and partly secondary cracking of tar and coke generated in the second stage.

\section{Conclusion}

In present study, the behavior of sediment pyrolysis at different heating rates were investigated by TG. Comparison to the TG and DTG curves at $10^{\circ} \mathrm{C} / \mathrm{min}$ and $20^{\circ} \mathrm{C} / \mathrm{min}$, the process of sediment pyrolysis could be considered as four stages at $10^{\circ} \mathrm{C} / \mathrm{min}$, which were the release stage of moisture and crystal water, the decomposition of light organic compounds, the decomposition of macromolecule organic matters and secondary cracking of coke and tar, and the decomposition of mineral salts. The pyrolysis process at $10^{\circ} \mathrm{C} / \mathrm{min}$ could demonstrated the sediment pyrolysis characteristics better than at $20^{\circ} \mathrm{C} / \mathrm{min}$. 


\section{Acknowledgements}

This work was financially support from National Nature Science Foundation of China (5116605), Key Project of Yunnan Province Nature Foundation (2015FA018), Analysis and testing foundations of Kunming University of Science and Technology(2016T20060036) and (2016M20152214024).

\section{References}

[1] $\mathrm{Wu}, \mathrm{X} . \mathrm{W}$., The status of organic pollution in Gaoyou Lake and the study on the adsorption characteristics of sediment. Harnessing the Huaihe River 24(1), 2013, 44-45.

[2] Wu, Z.F., Li, S.P., Li, W., Luo, H.L., Gu, Z.G., Wang, S., Feasibility analysis of gasification utilization of Eutrophic lake Dianchi dredged sediment, Journal of Kunming University of Science and Technology (Natural Science Edition) 1, 2016,72-76.

[3] Tian, Y., Zuo, W., Ren, Z.Y., Chen, D.D., Estimation of a novel method to produce bio-oil from sewage sludge by microwave pyrolysis with the consideration of efficiency and safety. Bioresour. Technol. 102 (2), 2011, 2053-2061.

[4] Smidt, E., Parravicini, V., Effect of sewage sludge treatment and additional aerobic post-stabilization revealed by infrared spectroscopy and multivariate data analysis. Bioresour. Technol. 100 (5), 2009, 1775-1780.

[5] Montusiewicz, A., Lebiocka, M., 2011. Co-digestion of intermediate landfill leachate and sewage sludge as a method of leachate utilization. Bioresour. Technol. 102(3), 2563-2571.

[6] Samolada, M.C., Zabaniotou, A.A., Comparative assessment of municipal sewage sludge incineration, gasification and pyrolysis for a sustainable sludge-to-energy management in Greece. Waste Management 34, 2014,411-420.

[7] Wang, Y.X.,, Ning, P., Gu, J.J., Experimental investigation on the CO-gasification of Dianchi sediment and lignite for hydrogen production in supercritical water. Chemical Industry and Engineering Progress 32(8), 2013, 1960-1966.

[8]Gu, Z.G., Wu, M., Li, K., Ning, P., Variation of heavy metal speciation during the pyrolysis of sediment collected from the Dianchi Lake, China. Arabian Journal of Chemistry 7, 2013,3-9.

[9]Gao, N.B., Li, J.J., Li, A.M., Duan, Y., Wang, Z., Thermal analysis and products distribution of dried sewage sludge pyrolysis. J. Anal. Appl. Pyrol. 105, 2014, 43-48.

[10] Ren, Q.Q., Zhao, C.S., Wu, X., Liang, C., Chen, X.P., Shen, J.Z., Tang, G.Y., Wang, Z., TG-FTIR study on co-pyrolysis of municipal solid waste with biomass.Bioresour. Technol. 100, 2009, 4045-4057. 